\title{
MEREDUPNYA MEDIA CETAK, DAMPAK KEMAJUAN TEKNOLOGI INFORMASI
}

\section{Budi Arista Romadhoni}

Program Studi Magister Ilmu Komunikasi FISIP UNDIP budi.dhoni@gmail.com

\begin{abstract}
The closing of national and international print media is the impact of technological development today. Print media is faced with the high cost of production and the change of society using mass media to seek information. Invention Information technology and communication that allows all forms of information to digital create a major impact on the media, especially print media. Online media provides a new color for the press and news readers, the news is fast, easy to access, and cheap. Media that can not keep up with technology will be closed.
\end{abstract}

Keywords: Newspaper, Information and Communication Technologies

\begin{abstract}
Abstrak
Tutupnya media cetak dikancah nasional maupun internasional merupakan dampak perkembangan teknologi saat ini. Media cetak dihadapkan dengan mahalnya biaya produksi dan perubahan masyarakat menggunakan media massa untuk mencari informasi. Penemuan Teknologi informasi dan komunikasi yang memungkinkan segala bentuk informasi menjadi digital menciptakan dampak besar pada media, terutama media cetak. Media online memberikan warna baru untuk kalangan pers dan para pembaca berita, yaitu berita yang cepat, mudah di akses, dan murah. Media yang tidak dapat mengikuti perkembangan teknologi akan banyak yang tutup.
\end{abstract}

Kata Kunci: Media Cetak, Teknologi Informasi 


\section{A. PENDAHULUAN}

Media cetak di tahun 2017 kian nampak terpuruk, tidak hanya di kancah nasional, di kancah internasionalpun mulai bergejolak. Bisnis media cetak ditinggalkan para pemiliknya akibat perkembangan teknologi informasi. Pada realitanya media cetak memang mulai ditinggalkan para pembacanya, kalangan anak muda kini lebih suka membuka media massa melalui ponsel, komputer, atau perangkat digital lainnya yaitu media Online.

Pada buku Teori Komunikasi Analisis dan Aplikasi West \& Turner "Media massa adalah saluran atau cara pengiriman pesanpesan ke massa atau audiens. Sedangkan komunikasi massa adalah komunikasi kepada khalayakluas dengan menggunakan media massa" (West \& Turner, 2008: 41). Sifat media massa yang serba hadir saat ini, keberadaannya tidak dapat dipisahkan dari kehidupan manusia. Perkembangan teknologi media, telah mengubah wajah dunia, batas, jarak dan waktu yang menjadi kendala masa lalu, kini telah teratasi melalui media online atau internet.

Surat kabar merupakan media massa yang paling tua dibandingkandenganmedia massa lainnya. Sejarah mencatat keberadaan surat kabar dimulai sejak ditemukannya mesin cetak oleh Johann Gutenberk di Jerman. Sedangkan kebaradaan surat kabar di Indonesia ditandai dengan perjalanan panjang melalui lima periode yakni masa penjajahan Belanda, penjajahan Jepang, menjelang kemerdekaan, dan awal kemerdekaan.

Posisi media cetak pada tahun 2014 berada diurutan keempat menggambarkan ketatnya media massa saat ini. Fakta itu berdasarkan data yang dikemukakan lembaga riset Nielsen, bahwa konsumsi media dikota-kota baik di Jawa maupun luar Jawa menunjukan televisi masih menjadi medium utama yang dikonsumsi masyarakat Indonesia (95\%), disusul oleh internet atau media online (33\%), Radio (20\%), surat kabar $(12 \%)$, tabloid $(6 \%)$, dan majalah (5\%). (sumber http://www. nielsen.com/id/ed/press-room/2014/ nielsen-konsumsi-media-lebih-tinggi-diluar-jawa.html).

Meredupnya media cetak merupakan perubahan pola hidup manusia saat ini yang sudah beralih dengan teknologi terbaru dan digital. Masyarakat informasi merupakan gambaran dari mereka yang telah tergantung pada jaringan informasi elektronik yang rumit serta aktivitas komunikasi (Melody dalam McQuail, 2011:114).

Dengan kata lain masyaratakat informasi menghadirkan wujud nyata dari apa yang dikatakan marshal McLuhan sebagai global village. Matafora ini akan terlihat berbeda ketika kita memperbandingkan dengan ratusan tahun yang lalu, di mana kita dapat melihat bahwa kini kita bisa memperoleh informasi yang lebih banyak mengenai bangsa dan budaya asing disertai dengan akses yang lebih mudah dan cepat dalam memperoleh informasi tersebut (Ess, 2001: vii).

Perubahan sosial ini terlihat dari struktur jaringan masyarakat kontras dengan masyarakat industri di abad ke-19 dan ke20 (McQuail, 2011:115). Kehadiran masyarakat informasi global ini merupakan 
efek yang melekat pada ekspansi teknologi digital di berbagai belahan dunia termasuk di Indonesia.

\section{B. PEMBAHASAN}

\section{Menurunnya Pembaca Media Cetak}

Pembaca media cetak kini mulai menurun drastis, yang dulu menjadi primadona, kini sudah mulai tersingkir karena majunya teknologi media. Menurut survey Nielsen yang di publis oleh kompas. com pada 2009 menyebutkan Hasil survei Nielsen menunjukkan bahwa angka pembaca koran semakin menurun secara signifikan, dari perolehan 28 persen pada kuartal pertama tahun 2005 menjadi hanya 19 persen pada kuartal kedua tahun 2009.

Kemudian di tahun 2017 kembali merilis hasil survey berdasarkan survey Nielsen Consumer Media View yang dilakukan di 11 kota di Indonesia, penetrasi Televisi masih memimpin dengan 96 persen disusul dengan Media Luar Ruang (53\%), Internet (44\%), Radio (37\%), Koran (7\%), Tabloid dan Majalah (3\%). Keberadaan internet sebagai media dengan tingkat penetrasi yang cukup tinggi menjadi indikasi bahwa masyarakat Indonesia semakin gemar mengakses berbagai konten melalui media digital.

Dari hasil survei Nielsen tersebut dapat menunjukan pembaca Koran mulai berkurang dan ditinggalkan. Penurunan sirkulasi penjualan media cetak juga didukung dengan lahirnya generasi muda yanglahir diera90an. Mereka disebutsebagai generasi digital negative atau sering disebut generasi milenial yaitu generasi yang lahir diera berkembangnya teknologi perangkat digital seperti komputer, smartphone, musik digital, kamera digital dan jangkauan jaringan internet yang sangat mudah dan cepat. Perangkat digital smartphone dan komputer menjadi alat utama menelusuri informasi di seluruh dunia. Dan mereka sudah jarang mendapatkan informasi dari media cetak, dan tabloid sehingga banyak surat kabar berpotensi kehilangan para pembaca mudanya.

Survey Nielsen Consumer \& Media View (CMV) kuartal II 2016 yang dilakukan di 11 kota di Indonesia, hanya 9 persen dari generasi muda yang saat ini masih membaca koran, majalah atau tabloid dalam bentuk cetak. Sisanya, lebih memilih mendapatkan informasi dari televisi atau internet. Nielsen membagi Generasi dalam dua area. Kelompok pertama berusia 1014 tahun atau yang disebut anak-anak dan kelompok lainnya 15-19 tahun, disebut remaja. Di kelompok pertama, kebiasaan membaca media cetak hanya dilakukan 4 persen anak. Sisanya sebanyak 98 persen memilih menghabiskan waktu menonton televisi, 13 persen bermain internet, 10 persen memakai televisi berbayar, dan 7 persen mendengarkan radio. Lalu di kalangan remaja, hanya 9 persen yang masih membaca dalam bentuk cetak, mulai dari koran, majalah dan tabloid. 97 persen memilih televisi, 81 persen memilih internet, 14 persen mendengarkan radio dan sisanya televisi berbayar sebanyak 10 persen. 


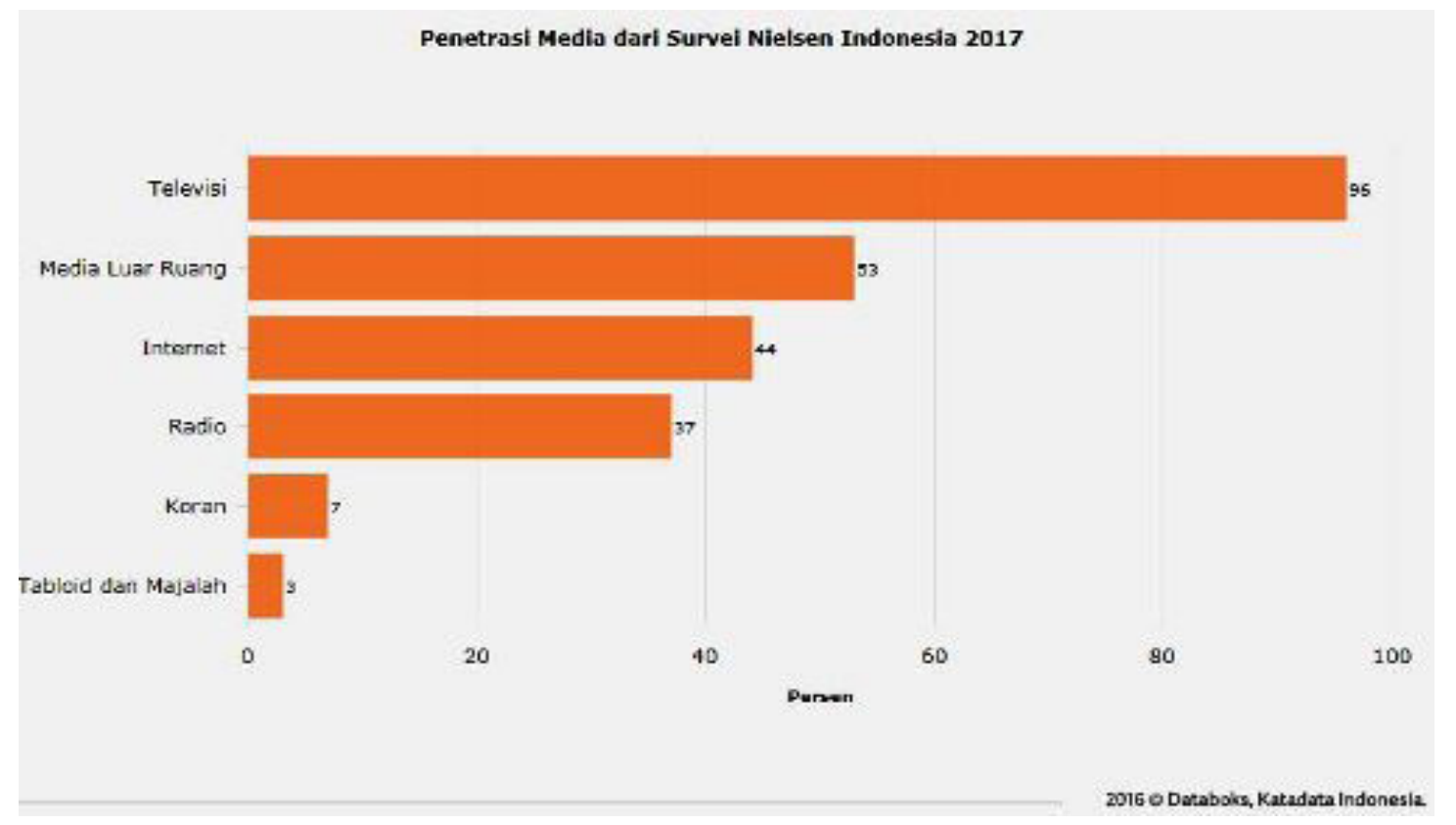

Gambar 1. Penetrasi Media

Sumber: Nielsen.com

Penurunan jumlah pembaca ini secara langsung akan berpengaruh pada jumlah sirkulasi dan akan diikuti oleh penurunan pendapatan iklan media cetak itu sendiri. Penurunan pembaca ini sudah masuk taraf mematikan, Dalam rentang waktu 2010 awal hingga tahun ini sejumlah media cetak di kancah nasional mulai berguguran seperti Jakarta Globe dan harian bola menerbitkan edisi terakhir pada 31 Oktober 2015, kemudian sinar harapan pada awal januari 2016, harian soccer 2014, Majalah Fortune, hai, chip dan jeep, media cetak harian, mingguan, bulanan. dan terakhir Koran Sindo Menutup Koran Harian lokalnya, media cetak bertumbangan menghadapi ketatnya persaingan dan perubahan pola hidup manusia.

Dikancah internasional, media cetak juga sudah banyak yang berguguran, seperti majalah playboy dan Wall Street Journal Surat kabar ekonomi tersohor di dunia, Wall Street Journal keteteran menghadapi persaingan dunia pers yang mulai berubah ke era digital. Pendapatan iklan yang makin menyusut membuat media yang masuk grup News Corp milik Rupert Murdoch asal Amerika tersebut terpaksa menutup edisi cetak di Eropa dan Asia. "Era digital yang berubah cepat membuat Wall Street Journal melakukan transformasi bisnis. Sepanjang tahun lalu, Wall Street Journal mulai menerapkan rencana bisnis yang mereka sebut sebagai "WSJ 2020". Ini merupakan rencana tiga tahun untuk menyesuaikan diri dengan selera pembaca yang lebih memilih mendapatkan berita lewat ponsel pintar mereka". (http://internasional. kontan.co.id/news / wall-street-journaltutup-edisi-cetak-eropa-asia).

\section{New Media dan Media Online}

Kehadiran new media menawarkan speed and space, di mana new media membuka peluang bagi kehadiran informasi-informasi yang tidak dapat ditemukan dalam bentuk hard copy media convensional. Format 
multimedia yang ditawarkan juga lebih inovatif dan lebih menarik (Fenton, 2010: 7). Dengan kehadiran new media menciptakan menciptakan digitalisasi informasi, yang memungkinkan akselerasi penyebarluasan informasi dan mempermudah penciptaan masyarakat informasi yang setara. Transisi dari old media ke new media menciptakan ruang publik yang lebih fleksibel dan cepat terhadap akses ke media.

Munculnya media baru dalam perkembangan teknologi komunikasi membawa dampak dalam komunikasi massa. Internet tidak hanya berkaitan dengan produksi media dan dengan distribusi pesan, tetapi juga dapat disetarakan dengan pengolahan, pertukaran dan penyimpanan. Media baru merupakan lembaga komunikasi publik juga privat dan diatur (atau tidak) dengan layak. Kinerja mereka tidak seteratur sebagaimana media massa yang professional dan birokratis, setidaknya dalam media baru ini bebas dari control. Dalam hal ini McQuail (2011:153) merumuskan perubahan utama yang berkaitan dengan munculnya media baru: (1) Digitalisasi dan konvergensi atas segala aspek media. (2) Interaksi dan konektivitas jaringan yang semakin meningkat. Mobilitas dan delokasi yang mengirim dan menerima. (4) Adaptasi terhadap peranan publikasi dan khalayak. (5) Munculnya beragam bentuk baru 'pintu' (gateway) media. (6) Pemisahan dan pengaburan dari lembaga media.

Umumnya kita akan berpikir tentang media cetak, televisi, dan radio (media tradisional/konvensional) itulah yang dalam kajian media pasca tahun 1960-an disebut sebagai media-media tradisional.
Penyebutan "tradisional" tentu saja merupakan konsekuensi dari adanya sesuatu yang lebih baru, akan tetapi terlebih dahulu perlu kita pahami perubahan apa yang terjadi pada tahun-tahun tersebut. Setidaknya terdapatempatfactor perubahan sosial, ekonomi, dan budaya:

1. Pergeseran dari modern ke postmodern: terjadinya perubahan yang mendasar dan struktural dalam masyarakat, kebudayaan, dan perekonomian pada tahun 1960-an.

2. Proses globalisasi yang semakin intensif: hilangnya sekat-sekat Negara dalam perdagangan, organisasi usaha, budaya, identitas, hingga kepercayaan.

3. Perubahan dari era industri manufaktur ke erainformasi dengan berkembangnya internet yang dimulai sejak proyek Arpanet ditahun 1960-an.

4. Terjadinya desentralisasi tata geopolitik yang sebelumnya telah mapan dan tersentralisasi: melemahnya mekanisme kekuasaan dan control dari negaranegara Barat. (Lister.2009: 10-11)

Dari prinsip-prinsip di atas, dapat kita pahami new media adalah digitalisasi teknologi dan budaya pada tahap produksi, distribusi, hingga konsumsi. Maka, totalitas perubahan-perubahan tersebut tentu saja menuntut pembaharuan pemahaman (upgrade) dan ketrampilan dari para kreator media maupun para penikmat media untuk mengupdate sarana mereka untuk mencari informasi.

Persaingan media massa sangatlah ketat, ketika industri cetak makin mahal, muncul media-media massa baru yang 
Hall (2001, h.16) juga sempat memprediksi bahwa dalam kurun waktu lima tahun, akan ada lebih banyak masyarakat di Negara berkembang yang mengakses berita dari media internet dibandingkan dengan cara lama yaitu surat kabar. Selain itu Hall juga memprediksi Sembilan atau sepuluh perusahaan media global akan mampu mendominasi (oligopoly) terhadap pasar dunia.

\section{SIMPULAN}

Bisnis media cetak kini tak lagi menguntungkan, harga produksi yang mahal dan sasaran pembaca tidak lagi mencakup ke segala kalangan menjadi alasan para pemilik media cetak menutup bisnisnya, maka media cetak yang masih bertahan menghadapi tantangan yang serius.

Di tengah ketatnya persaingan tidak berbuat apa-apa bukan solusi yang tepat, media cetak harus mentransformasi diri untuk ikut menguasai perkembangan teknologi digital media. Di era digital saat ini muncul new media dan masyarakat pada realitanya mulai meninggalkan media tradisional atau konvensional yaitu Koran, Radio dan nantinya televisi juga akan digantikan oleh televise online.

Media cetak suatu saat nanti mungkin akan hilang. Tetapi sebagai sebuah media informasi yang terus update dengan realitas sosial akan terus langgeng, bahkan dengan isi yang lebih kaya. Paradigma masyarakat untuk mendapatkan informasi melalui internet adalah gratis menyulitkam media cetak untuk menentukan harga Koran yang diedarkan kepada pembaca atau pelanggan.
Perkembangan teknologi digital telah meredupkan bisnis media cetak di Indonesia maupun dunia. Disisi lain perkembangan teknologi dan perubahan pembaca media cetak ke Online akan menyelamatkan peradaban dan sekaligus melestarikan lingkungan yaitu mengurangi penggunaan kertas. 


\section{DAFTAR PUSTAKA}

Fonton, Natalie (Ed). (2010). New Media, Old News: Journalisme EDemocracy in the Gigital. Age. E-book. London: Sage Publications

Hall, Jim. 2001. Online Jurnalisme: A Critical Teory. London:Pluto Press.

West Richard dan Lynn H. Turner. 2008. Pengantar Teori Komunikasi: Analisis Dan Aplikasi. Buku 1 edis ke-3 Terjemahan Maria Natalia Damayanti Maer. Jakarta: Salemba Humanika

Lister, Martin, et.al. 2009. New Media: a Critical Introduction. London: Routledge.

Salwen, Michael B, Bruce Garrison, Paul D Dricoll. (2005). Online News and the public. New Jersey: Lawrence Erlbaum Associates.

Manovich, Lev. 2001.The Language of New Media. Massachusetts: MIT Press.

McQuail, Dennis. (2011). Teori Komunikasi Massa (ed 6). Jakarta: Salemba Humanika.

Sumber Website

h t t p : / / t e k n o.k o m pa s . c o m / $\mathrm{read} / 2009 / 07 / 16 / 16015757 /$ survei. nielsen.pembaca.media.cetak.makin. turun

http:// www.nielsen.com/id/ed/pressroom/2014/nielsen-konsumsimedia-lebih-tinggi-di-luar-jawa. html

http://www.nielsen.com/id/en/ press-room/2017/TREN-BARUDI-KALANGAN-PENGGUNAINTERNET-DI-INDONESIA.html http:/ / internasional.kontan.co.id/news / wall-street-journal-tutup-edisicetak-eropa-asia. 